\title{
SHELF LIFE OF MINIMALLY PROCESSED CARROT AND GREEN PEPPER ${ }^{1}$
}

\author{
Lucimeire PILON², Marília OETTERER ${ }^{3, *}$, Cláudio R. GALLO ${ }^{4}$, Marta H. F. SPOTO ${ }^{5}$
}

\section{SUMMARY}

The postharvest losses of horticultural products justify the use of preservation techniques. The processing not only adds value to the products, but also makes the products more convenient to the consumers. The objective of this research was to define the methodologies for the minimal processing of carrot and green pepper as to the type and intensity of the adoption of conservation techniques, and to monitor the products after processing through microbiological, physicochemical and nutritional analysis. The vegetables were washed and they were immersed in cold $\left(7^{\circ} \mathrm{C}\right)$ water with $100 \mathrm{mg} \mathrm{L}^{-1}$ free chlorine for sanitation, followed by centrifugation for $5 \mathrm{~min}$. The product was put into BOPP/LDPE (biaxially orientated polypropylene/low-density polyethylene) plastic bags, which were sealed under atmospheric air, vacuum and modified atmosphere $\left(2 \% \mathrm{O}_{2}, 10 \% \mathrm{CO}_{2}, 88 \% \mathrm{~N}_{2}\right)$ and stored at $1{ }^{\circ} \mathrm{C} \pm 1{ }^{\circ} \mathrm{C}$. The approximate composition of the vegetables stayed stable during the storage period, in the three tested treatments. The contents of vitamin $\mathrm{C}$ for the samples of minimally processed carrot and green pepper did not present differences among treatments. The contents of $\beta$-carotene decreased slightly during the storage period for the minimally processed carrot and green pepper. After processing, carrot and green pepper had psychrotrophic counts of $10^{2}-10^{5}$ and $10^{3}-10^{6} \mathrm{CFU} \mathrm{g}^{-1}$, respectively. Anaerobic mesophiles and total coliforms were found in green peppers, representing $1.6 \times 10^{3}-7.4 \times 10^{5}$ and $<10 . \mathrm{g}^{-1}-7.4 \times 10^{5}$, respectively. Total and fecal coliforms, anaerobic mesophiles and Salmonella were not found in carrots. Salmonella was not found in green pepper.

Keywords: vegetable, minimal processing, modified atmosphere, vacuum packaging, refrigeration.

\section{RESUMO}

VIDA ÚTIL DE CENOURA E PIMENTÃO MINIMAMENTE PROCESSADOS. As perdas pós-colheita de alimentos hortícolas justificam a adoção de técnicas de conservação. Uma vez beneficiados, esses produtos permitem agregar valor à produção primária e se tornam de conveniência ao consumidor. Este trabalho teve como objetivo definir as metodologias do processamento mínimo de cenoura e pimentão quanto ao tipo e intensidade de adoção das técnicas de barreiras e monitorar os produtos após o processamento, através de análises microbiológica, físico-química e nutricional. As hortaliças foram lavadas e sanificadas com hipoclorito de sódio, 100 mg $\mathrm{L}^{-1}$ de cloro livre, durante $15 \mathrm{~min}$ em água refrigerada $\left(7^{\circ} \mathrm{C}\right)$, e a seguir centrifugadas por 5 min. O produto foi acondicionado em sacos plásticos com filme BOPP/PEBD (polipropileno biorientado/polietileno de baixa densidade), selados sob ar atmosférico, vácuo e atmosfera modificada $\left(2 \% \mathrm{O}_{2}, 10 \% \mathrm{CO}_{2}\right.$ e $\left.88 \% \mathrm{~N}_{2}\right)$, e a seguir armazenados a $1^{\circ} \mathrm{C} \pm 1^{\circ} \mathrm{C}$. A composição centesimal das hortaliças permaneceu estável durante o período de armazenamento, nos três tratamentos testados. Os teores de vitamina C, para as amostras de cenoura e pimentão minimamente processados, não apresentaram diferenças entre os tratamentos. Os teores de $\beta$-caroteno diminuíram ligeiramente durante o período de armazenamento para a cenoura e pimentão minimamente processados. Após o processamento, a cenoura e o pimentão obtiveram contagens para psicrotróficos de $10^{2}-10^{5}$ e $10^{3}-10^{6}$ UFC $\mathrm{g}^{-1}$, respectivamente Foram constatados anaeróbios mesófilos e coliformes totais em pimentões, da ordem de $1,6 \times 10^{3}$ a $7,4 \times 10^{5}$ e $<10 / g$ a $7,4 \times 10^{5}$, respectivamente. Nas cenouras, não foram detectados coliformes totais e fecais, anaeróbios mesófilos e Salmonella em nenhum dos tratamentos. Salmonella não foi detectada nos pimentões.

Palavras-chave: hortaliças, processamento mínimo, atmosfera modificada, embalagem a vácuo, refrigeração.

\section{1 - INTRODUCTION}

In Brazil, despite of the availability of agricultural products there are still significant losses due to inadequate use of technology during cultivation, handling, storage and conservation. An alternative technology to minimize postharved losses is the minimal processing of fruits and vegetables [9].

The demand for minimally processed vegetables has promoted an increase in the quality and variety of the products. Conservation technologies, especially refrigeration and modified atmosphere assure the quality of these products. Temperatures between $0^{\circ} \mathrm{C}$ and $3^{\circ} \mathrm{C}$ can extend the shelf life

\footnotetext{
${ }^{1}$ Recebido para publicação em 6/4/2005. Aceito para publicação em 23/1/2006 (001504)

${ }^{2}$ USP/ESALQ - Programa de Pós-Graduação em Ciência e Tecnologia de Alimentos

${ }^{3}$ USP/ESALQ - Depto. de Agroindústria, Alimentos e Nutrição, C.P. 9 13418-900 - Piracicaba, SP - Brasil.E-mail:moettere@esalq.usp.br

${ }^{4} U S P / E S A L Q$ - Depto. de Agroindústria, Alimentos e Nutrição, C.P. 9 - 13418-900 - Piracicaba, SP - Brasil

${ }^{5}$ USP/ESALQ - Depto. de Agroindústria, Alimentos e Nutrição, C.P. 9 - 13418-900 - Piracicaba, SP - Brasil

*A quem a correspondência deve ser enviada
}

of minimally processed vegetables from 5 to 18 days, since the quality degradation is retarded by the lower temperature causing a reduction in the respiratory rate [39]. Reviews by ZAGORY \& KADER [46]; CARLIN et al. [8]; IZUMI et al. [19]; GIL et al. [16] and JAYAS \& JEYAMKONDAN [21] show the relevance of the use of $\mathrm{O}_{2}, \mathrm{CO}_{2}$ and $\mathrm{N}_{2}$ modified atmosphere in the storage of minimally processed vegetables.

The natural variability in the raw material and its dynamic response to processing and storage conditions may render it impossible to identify a truly optimal storage atmosphere. Additional refinements in recommendations for the controlled atmosphere (CA) and modified atmosphere (MA) storage of fruits and vegetables will continue to accrue through empirical observations derived from traditional experiments [38].

The effect of minimal processing on the maintenance of the nutritional quality of vegetables has not yet been established. Therefore, there is a need for information on the effects of minimal processing, type of package and the contents of nutrients in these products [17].

The objective of this research was to define methodologies for minimal processing of carrot and green 
pepper as to the type and intensity of the adoption of conservation techniques, and to monitor the storage after processing through microbiological, physicochemical and nutritional analysis.

\section{2 - MATERIAL AND METHODS}

\section{1 - Raw material}

'Nantes' carrots (Daucus carota L.) were harvested after 120 days in the field. The samples were randomly collected in the morning for the experiment in Piedade, SP $\left(23^{\circ} 43^{\prime} \mathrm{S}\right.$; $47^{\circ} 25^{\prime} \mathrm{W}$; $900 \mathrm{~m}$ ). 'Magali' green peppers (Capsicum annuum L.) harvested after 120 days in the field were obtained at CEASA (Centrais de Abastecimento e Serviços Auxiliares) in Piracicaba, SP (22 $42^{\prime}$ S; 47³8'W; $546 \mathrm{~m}$ ).

\section{2 - Carrot and green pepper processing}

Carrot samples were placed in ice boxes, transported by ground to Piracicaba, SP, and placed under refrigeration at $1^{\circ} \mathrm{C} \pm 1^{\circ} \mathrm{C}$ overnight. Green pepper samples were brought from CEASA in the morning in plastic boxes.

The sanitation of the process was ensured by personal hygiene and the use of aprons and gloves. All the utensils used were previously sanitized in $200 \mathrm{mg} \mathrm{L}^{-1}$ of free chlorine.

The carrots were washed in running water, peeled with sharp stainless steel knives and immersed in cold water at $7^{\circ} \mathrm{C}$ for $15 \mathrm{~min}$. Carrots were cut in cubes $(1.0 \times 0.9 \mathrm{~cm})$ with a vegetable chopper processor. Green peppers were transversally sliced with stainless steel knives ( $2 \mathrm{~mm}$ - thick slices). These were then immersed in cold water $\left(7^{\circ} \mathrm{C}\right)$ with $100 \mathrm{mg}$ of free chlorine $\mathrm{L}^{-1}$ at $\mathrm{pH} 7.0$ for $15 \mathrm{~min}$, for sanitation, followed by centrifugation at 550$900 \mathrm{G}$ for $5 \mathrm{~min}$.

The products were put into multilayered laminated BOPP/LDPE (biaxially orientated polypropylene/low-density polyethylene) plastic bags. Bags with $400 \mathrm{~g}$ of chopped carrots and bags with $250 \mathrm{~g}$ of sliced green pepper were sealed under air, vacuum or modified active atmosphere ( $2 \%$ of $\mathrm{O}_{2}, 10 \%$ of $\mathrm{CO}_{2}$ and $88 \%$ of $\mathrm{N}_{2}$ ). The products were kept at $1^{\circ} \mathrm{C} \pm 1^{\circ} \mathrm{C}$ for 21 days.

\section{3 - Physicochemical analysis}

Total nitrogen content was detected using the Kjeldahl method based on SARRUGE \& HAAG [36]. The percentages of nitrogen were transformed into protein content by multiplying by a conversion factor of 6.25. Moisture, lipids and ash contents were assessed using the AOAC [2] method. All analyses were performed in triplicate.

Titratable acidity of the filtered sample was measured with sodium hydroxide at $0.01 \mathrm{~N}$ (the results for the carrot and green pepper were expressed in \% of malic and citric acids, respectively) and $\mathrm{pH}$ was determined in the triturated sample by a digital potentiometer [2].
The content of ascorbic acid was determined with Tillman's reagent (2.6 dichlorophenolindophenol) titration until a slightly pink coloration was stabilized for $15 \mathrm{sec}$. The results were expressed in mg of ascorbic acid per $100 \mathrm{~g}$ of sample [31].

Mineral contents were determined by the method of SARRUGE \& HAAG [36] with quantification by atomic absorption spectrophotometry, except for potassium which was quantifyed by flame photometry.

Determination of $\beta$-carotene contents were based on RODRIGUEZ-AMAYA et al. [33] procedure, which consists of an extraction, followed by pigment separation by column chromatography and reading in a spectrophotometer. The results were expressed in milligrams of $\beta$-carotene per $100 \mathrm{~g}$ of the sample.

\section{4 - Microbiological analysis}

For microbiological analysis samples were collected on the $1^{\text {st }}, 7^{\text {th }}, 14^{\text {th }}$, and $21^{\text {st }}$ day of storage in triplicates for each treatment.

For the total count of anaerobic mesophiles, samples were diluted at $10^{-1}$ with peptonized water at $0,1 \%$ and then were inoculated in Plate Count Agar (PCA) and incubated at $35^{\circ} \mathrm{C}$ for $48 \mathrm{~h}$ in anaerobiosis. For psychrotrophics, samples were diluted at $10^{-1}, 10^{-2}$ and $10^{-3}$ and the incubation was carried out for 10 days at $7^{\circ} \mathrm{C}$, according to VANDERZANT \& SPLITTSTOESSER [45].

The "Simplate" methodology was used for the total and fecal coliforms count, with kits composed of disposable plates with 84 cavities, manufactured by Idexx Laboratories, in 1996. The plates were inoculated with $1 \mathrm{~mL}$ of dilutions $10^{-1}$ and $10^{-2}$ and agitated with circular movements. After discarding the excess, the plates were inverted and incubated at $35^{\circ} \mathrm{C}$ for $24 \mathrm{~h}$ for a later reading of the results. This methodology received an approval certificate (970301) by the Association of Official Analytical Chemists (AOAC) on March 05, 1997 [3].

For Salmonella analysis the "Oxoid Salmonella Rapid Test” - FT201A kit, was used. A previous enrichment of each sample was done, inoculating $25 \mathrm{~g}$ of the vegetable in an Erlenmeyer with $225 \mathrm{~mL}$ of sterilized peptonized water. The flasks were incubated at $35 \pm 2^{\circ} \mathrm{C}$ for $24 \mathrm{~h}$. One $\mathrm{mL}$ of the pre-enriched sample and the kit were inoculated at $41^{\circ} \mathrm{C}$ for $24 \mathrm{~h}$ and the results were interpreted according to the sample colorations after incubation [41].

\section{5 - Statistical analysis}

The experiments were installed using a completely randomized factorial design $(3 \times 4)$ with two replications. The three treatments were air, vacuum and modified atmosphere and the four storage periods were 1, 7, 14 and 21 days. The data obtained were submitted to analysis of variance by the Statistical Analysis System - SANEST [48] and polynomial regression analysis. 


\section{3 - RESULTS AND DISCUSSION}

\section{1 - Proximate composition analysis}

Moisture, lipids and ash values for green pepper, and protein values for carrot, showed differences among treatments (Table 1), however they were stable during 21 days storage at $1^{\circ} \mathrm{C} \pm 1^{\circ} \mathrm{C}$ for both in all 3 treatments. The moisture content for carrot and green pepper are in accordance with the data published by LUENGO et al. [26] and the contents of lipids (Table 1) are in agreement with FRANCO [12].

The values found for protein varied from 0.78 to $0.91 \mathrm{~g}$

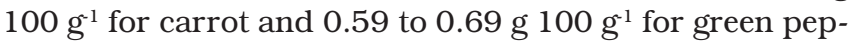
per, being similar to those mentioned in the Brazilian Table of Composition of Foods [43]: $1.0 \mathrm{~g} 100 \mathrm{~g}^{-1}$ for carrot and

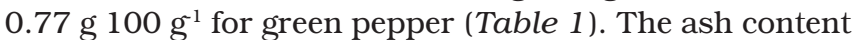
for carrot and green pepper were also in accordance with the Brazilian Table of Food Composition [43].

\section{2 - Titratable acidity}

The contents of titratable acidity were not affected by the storage period and did not present statistical differences among treatments for carrot and green pepper (Table 1). BENEDETTI et al. [4] found a decrease from 0.08 to $0.06 \mathrm{mg} 100 \mathrm{~g}$ of citric acid in sliced green peppers packed in polystyrene trays and stored for 10 days under temperatures of 5 and $10^{\circ} \mathrm{C}$ and CARLIN et al. [8] reported a decrease in malic acid in grated carrots packed under modified atmosphere $\left(10 \% \mathrm{O}_{2}\right.$ and $40 \%$ $\mathrm{CO}_{2}$ ) for 10 days at $10^{\circ} \mathrm{C}$.

KAKIOMENOU et al. [22] studied the sensory alterations in minimally processed carrots and demonstrated that there was an increase in its organic acids resulting in a reduction in the values of texture, characterized by softening of the tissues during storage.

\section{$3.3-\mathbf{p H}$}

In the minimally processed carrot, the average values found for $\mathrm{pH}$ ranged from 6.2 to 6.5 during the different storage periods (Table 2 ). The minimally processed green pepper had the $\mathrm{pH}$ average significantly affected during storage, presenting a variation of 5.4 to 6.3 (Table 3).

The $\mathrm{pH}$ increased in both experiments, during the refrigerated storage, which can be related to the lower organic acid values found. Similar results were obtained by FANTUZZI [10] and BITTENCOURTT et al. [7].

In experiments with cut cantaloupe melon stored at $4^{\circ} \mathrm{C}$, by 14 days, LAMIKANRA \& WATSON [24] evaluated the biochemical changes compared to stored whole melons at $20^{\circ} \mathrm{C}$. No significant changes were observed in titratable acidity, $\mathrm{pH}$, degrees Brix and organic acid content over a period of 14 days. At $20^{\circ} \mathrm{C}$, lactic acid was by far the dominant acid present after two days, differently from the fresh fruit in which oxalic, citric, malic and succinic acids were dominant.
The results found in this research differed from those reported by ABDUL-RAOUF et al. [1], who found a $\mathrm{pH}$ decrease with minimally processed mixed carrot, lettuce and cucumber salad packed under modified atmosphere $\left(3 \% \mathrm{O}_{2}\right.$ and $\left.97 \% \mathrm{~N}_{2}\right)$ and stored under temperatures of $5^{\circ} \mathrm{C}$, $12^{\circ} \mathrm{C}$ and $21^{\circ} \mathrm{C}$. GARCÍA-GIMENO \& ZURERA-COSANO [14] observed, in a mixed salad made of carrots, lettuce and purple cabbage, a pH decrease from 7.0 to 4.0 after 9 days of storage at $15^{\circ} \mathrm{C}$, concluding that this reduction could be related to the higher concentration of $\mathrm{CO}_{2}$ found at this temperature.

Cactus pear fruits (Opuntia ficus indica Mill, cv. 'Gialla') placed in plastic boxes sealed with a film with high permeability to gases, and kept at $4^{\circ} \mathrm{C}$ for 9 days, showed significant $\mathrm{pH}$ and acidity changes without, however, adversely affecting the sensorial properties [30].

TABLE 1 - Average values of the four storage periods (1, 7, 14 and 21 days) for moisture, lipids, protein, ash, titratable acidity, vitamin $\mathrm{C}, \beta$-carotene and $\mathrm{pH}$ in minimally processed carrot and green pepper, packed under air, vacuum and modified atmosphere (MA), and stored at $1{ }^{\circ} \mathrm{C} \pm 1^{\circ} \mathrm{C}$.

\begin{tabular}{|c|c|c|c|c|c|}
\hline & \multirow{3}{*}{ Treatments } & \multicolumn{4}{|c|}{ Average } \\
\hline & & Moisture & Lipids & Protein & Ash \\
\hline & & ----- & ---- g 10 & $\mathbf{g}^{-1}$ & ------- \\
\hline \multirow[t]{3}{*}{ Carrot } & Air & $90.08 \mathrm{a}$ & $0.108 a$ & $0.879 a$ & $0.706 \mathrm{a}$ \\
\hline & Vacuum & $90.32 \mathrm{a}$ & $0.114 \mathrm{a}$ & $0.800 \mathrm{~b}$ & $0.704 \mathrm{a}$ \\
\hline & MA & $90.21 \mathrm{a}$ & $0.112 \mathrm{a}$ & $0.836 a b$ & $0.707 \mathrm{a}$ \\
\hline \multirow{5}{*}{$\begin{array}{l}\text { Green } \\
\text { pepper }\end{array}$} & Air & $94.16 \mathrm{~b}$ & $0.081 \mathrm{a}$ & $0.651 \mathrm{a}$ & $0.273 a$ \\
\hline & Vacuum & $94.48 \mathrm{a}$ & $0.080 \mathrm{a}$ & $0.635 a$ & $0.253 \mathrm{~b}$ \\
\hline & MA & $94.35 \mathrm{ab}$ & $0.073 b$ & $0.625 \mathrm{a}$ & $0.265 \mathrm{a}$ \\
\hline & & $\begin{array}{c}\text { Titratable } \\
\text { acidity }\end{array}$ & Vitamin C & $\beta$-carotene & $\mathrm{pH}$ \\
\hline & & 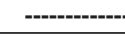 & g 100 g $^{-1}$ & -1-n-n-.-- & \\
\hline \multirow[t]{3}{*}{ Carrot } & Air & $0.062 \mathrm{a}$ & $13.54 \mathrm{a}$ & $3.509 b$ & $6.53 \mathrm{a}$ \\
\hline & Vacuum & $0.061 \mathrm{a}$ & $14.59 \mathrm{a}$ & $4.000 \mathrm{a}$ & $6.39 \mathrm{a}$ \\
\hline & MA & $0.064 \mathrm{a}$ & $14.24 \mathrm{a}$ & $2.851 \mathrm{c}$ & $6.24 b$ \\
\hline \multirow{3}{*}{$\begin{array}{l}\text { Green } \\
\text { pepper }\end{array}$} & Air & $0.055 \mathrm{a}$ & $132.8 \mathrm{a}$ & $0.178 \mathrm{~b}$ & $5.77 \mathrm{a}$ \\
\hline & Vacuum & $0.055 a$ & $125.3 \mathrm{a}$ & $0.226 \mathrm{a}$ & $6.09 \mathrm{a}$ \\
\hline & MA & $0.056 \mathrm{a}$ & $130.3 \mathrm{a}$ & $0.180 \mathrm{~b}$ & $5.86 \mathrm{a}$ \\
\hline
\end{tabular}

Different letters in the columns show that samples are significantly different by the test of Tukey at 0.05

\section{4 - Vitamin C}

The contents of vitamin $\mathrm{C}$ for the samples of minimally processed carrot and green pepper did not present differences among treatments (Table 1). Vitamin $\mathrm{C}$ was retained until 21 days of storage for carrots in all treatments carried out.

Vitamin C levels oscillated with a slight decrease during the period of storage for green peppers (Table 3). Similar results were found by BENEDETTI et al. [4] in sliced green peppers packed in expanded polystyrene trays and wrapped in PVC (polyvinylchloride) film stored at $5^{\circ} \mathrm{C}$ for 10 days. The protective effect on the vitamin $\mathrm{C}$ retention expected for the vacuum packing was not observed. The vitamin was lost through an exsudate that occurred from the green pepper. TELES et al. [42] reported that on the $13^{\text {th }}$ 
storage day at $5^{\circ} \mathrm{C}$, minimally processed cabbages packed in polyolephine plastic films at modified atmosphere $(10 \%$ $\mathrm{O}_{2}, 5 \% \mathrm{CO}_{2}$ and $85 \% \mathrm{~N}_{2}$ ) had $80 \%$ of the vitamin $\mathrm{C}$ found at the beginning of the study.

Vitamin $\mathrm{C}$ and its antioxidant capacity were studied by PIGA et al. [30], in cactus pear fruits (Opuntia ficus indica Mill, cv. 'Gialla') placed in plastic boxes sealed with a film with high permeability to gases, and kept at $4^{\circ} \mathrm{C}$ for 9 days.

\section{5 - $\beta$-carotene}

The values of $\beta$-carotene in the minimally processed carrot and green pepper in all treatments varied significantly.

The content of $\beta$-carotene in the carrot packed under modified atmosphere presented the lowest values during the storage period (Table 1 ). The contents of $\beta$-carotene decreased continuously during the storage at $1^{\circ} \mathrm{C}$ in peeled carrots packed in polymeric film bags, with approximately $33 \%$ of the initial content after 28 days. Between the $14^{\text {th }}$ and $21^{\text {st }}$ days, there was a reduction in the $\beta$-carotene content in the treatment under air, which is in accordance with LI \& BARTH [25].

The green peppers had their contents of $\beta$-carotene reduced after the first week of storage for all treatments, remaining stable until the end of the experiment (Table 3). Similarly, HUSSEIN et al. [17] reported a reduction in contents of $\beta$-carotene in vacuum-packed green peppers on the $10^{\text {th }}$ day of storage. The values for the vacuum-packed samples were higher than the others during the whole storage period for both carrot and green pepper (Table 1).

\section{6 - Minerals}

All treatments for minimally processed carrots did not present significant variations of potassium, calcium, iron, manganese and zinc during the storage period.

Otherwise, the content of copper (8.98 to $5.20 \mathrm{mg} \mathrm{kg}$ $\left.{ }^{1}\right)$ reduced in the last two weeks to practically half of the initial value. Magnesium (0.99 to $0.77 \mathrm{~g} \mathrm{~kg}^{-1}$ ) and phosphorus (2.73 to $2.13 \mathrm{~g} \mathrm{~kg}^{-1}$ ) presented statistical differences $(\mathrm{p}<0.05)$, however they were practically stable during the storage period (Table 2).

The macro and micronutrients found in this study for the carrot samples in the four storage periods were higher than those found in fresh carrots in foods chemical composition tables, such as IBGE [18] and FRANCO [12]. However, they were lower than the ones found by FURLANI et al. [13]. Generally, the mineral content variation in the same variety of vegetables are due to several factors such as harvest time, time of the year, soil fertilization and type of soil [27].

For the minimally processed green pepper, the content of potassium, calcium, copper, iron, zinc and manganese oscillated only once along the period with no significant differences.

Otherwise, the content of magnesium (0.91 to $1.01 \mathrm{~g} \mathrm{~kg}^{-1}$ ) and phosphorus (2.15 to $2.31 \mathrm{~g} \mathrm{~kg}^{-1}$ ) showed statistical differences during the storage period (Table 3 ).

The contents and types of minerals were different for each product and treatment analyzed, showing that the atmospheres used in the packaging are unlikely to have influenced the variations.

TABLE 2 - Average values of the three treatments (air, vacuum and modified atmosphere - MA) for moisture, lipids, $\beta$-carotene, pH, copper, magnesium and phosphorus in minimally processed carrot, stored during four periods $(1,7,14$ and 21 days $)$, at $1^{\circ} \mathrm{C} \pm 1^{\circ} \mathrm{C}$

\begin{tabular}{|c|c|c|c|c|c|c|c|}
\hline \multirow{4}{*}{ Period (days) } & \multicolumn{7}{|c|}{ Carrot } \\
\hline & \multicolumn{7}{|c|}{ Variables } \\
\hline & Moisture & Lipids & $\beta$-carotene & $\mathrm{pH}$ & $\mathrm{Cu}$ & $M g$ & $\mathbf{P}$ \\
\hline & \multicolumn{2}{|c|}{ - g $100 \mathrm{~g}^{-1}$} & \multicolumn{2}{|l|}{$\mathrm{mg} 100 \mathrm{~g}^{-1}$} & \multicolumn{3}{|c|}{------------ g kg-1 -- } \\
\hline 1 & $89.656 \mathrm{~B}$ & $0.091 \mathrm{~B}$ & $3.809 \mathrm{~A}$ & $6.477 \mathrm{~A}$ & $8.983 \mathrm{~A}$ & $0.993 \mathrm{~A}$ & $2.730 \mathrm{~A}$ \\
\hline 7 & $90.022 \mathrm{AB}$ & $0.114 \mathrm{AB}$ & $3.768 \mathrm{~B}$ & $6.268 \mathrm{~B}$ & $8.500 \mathrm{~A}$ & $0.970 \mathrm{~A}$ & $2.769 \mathrm{~A}$ \\
\hline 14 & $90.389 \mathrm{~A}$ & $0.123 \mathrm{~A}$ & $3.322 \mathrm{C}$ & $6.281 \mathrm{AB}$ & $4.935 \mathrm{~B}$ & $0.657 \mathrm{~B}$ & $2.164 \mathrm{~B}$ \\
\hline 21 & $90.755 \mathrm{~A}$ & $0.117 \mathrm{~A}$ & $2.914 \mathrm{D}$ & $6.516 \mathrm{~A}$ & 5.205 B & $0.767 \mathrm{~B}$ & $2.134 \mathrm{~B}$ \\
\hline
\end{tabular}

Different letters in the columns show that samples are significantly different by the test of Tukey at 0.05

TABLE 3 - Average values of the three treatments (air, vacuum and modified atmosphere - MA) for moisture, lipids, ash, pH, Vitamin $\mathrm{C}, \beta$-carotene, magnesium and phosphorus in minimally processed green pepper, stored during four periods ( $1,7,14$ and 21 days), at $1^{\circ} \mathrm{C} \pm 1^{\circ} \mathrm{C}$

\begin{tabular}{|c|c|c|c|c|c|c|c|c|}
\hline \multirow{4}{*}{ Period (days) } & \multicolumn{8}{|c|}{ Green pepper } \\
\hline & \multicolumn{8}{|c|}{ Variables } \\
\hline & Moisture & Lipids & Ash & $\mathrm{pH}$ & Vitamin C & $\begin{array}{c}\beta- \\
\text { carotene }\end{array}$ & Mg & $\mathbf{P}$ \\
\hline & \multicolumn{4}{|c|}{ - } & \multicolumn{2}{|c|}{ 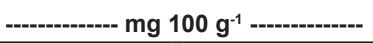 } & -----------.. & 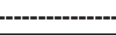 \\
\hline 1 & $94.161 \mathrm{~A}$ & $0.073 \mathrm{~B}$ & $0.270 \mathrm{~A}$ & $5.442 \mathrm{~B}$ & $138.850 \mathrm{~A}$ & $0.260 \mathrm{~A}$ & $0.956 \mathrm{~A}$ & $2.312 \mathrm{~A}$ \\
\hline 7 & $94.276 \mathrm{~A}$ & $0.077 \mathrm{~B}$ & $0.275 \mathrm{~A}$ & $5.752 \mathrm{~B}$ & $132.617 \mathrm{~A}$ & $0.196 \mathrm{~B}$ & $0.903 \mathrm{~B}$ & $2.174 \mathrm{~B}$ \\
\hline 14 & $94.391 \mathrm{~A}$ & $0.072 \mathrm{~B}$ & $0.255 \mathrm{~B}$ & $6.062 \mathrm{~A}$ & $126.383 \mathrm{~A}$ & $0.162 \mathrm{~B}$ & $1.023 \mathrm{~A}$ & $2.150 \mathrm{~B}$ \\
\hline 21 & $94.505 \mathrm{~A}$ & $0.090 \mathrm{~A}$ & $0.257 \mathrm{~B}$ & $6.372 \mathrm{~A}$ & $120.150 \mathrm{~A}$ & $0.160 \mathrm{~B}$ & $1.010 \mathrm{~A}$ & $2.241 \mathrm{~A}$ \\
\hline
\end{tabular}




\section{7 - Linear regression}

A linear regression analysis was done using as response variables the contents of moisture, lipids, $\mathrm{pH}, \beta$-carotene, phosphorus, magnesium and copper for carrot (Figure 1), and moisture, lipids, ash, $\mathrm{pH}$, vitamin $\mathrm{C}, \beta$-carotene, phosphorus and magnesium for green pepper, and the storage period as a predictor variable (Figure 2).

\section{8 - Microbiological analysis}

Results of microbiological analysis of minimally processed carrot were negative for total or fecal coliforms, anaerobic mesophiles and Salmonella. However, psychrotrophics grew slightly during the storage period of the samples packed under atmospheric, vacuum and modified atmosphere (Table 5). The minimally processed green

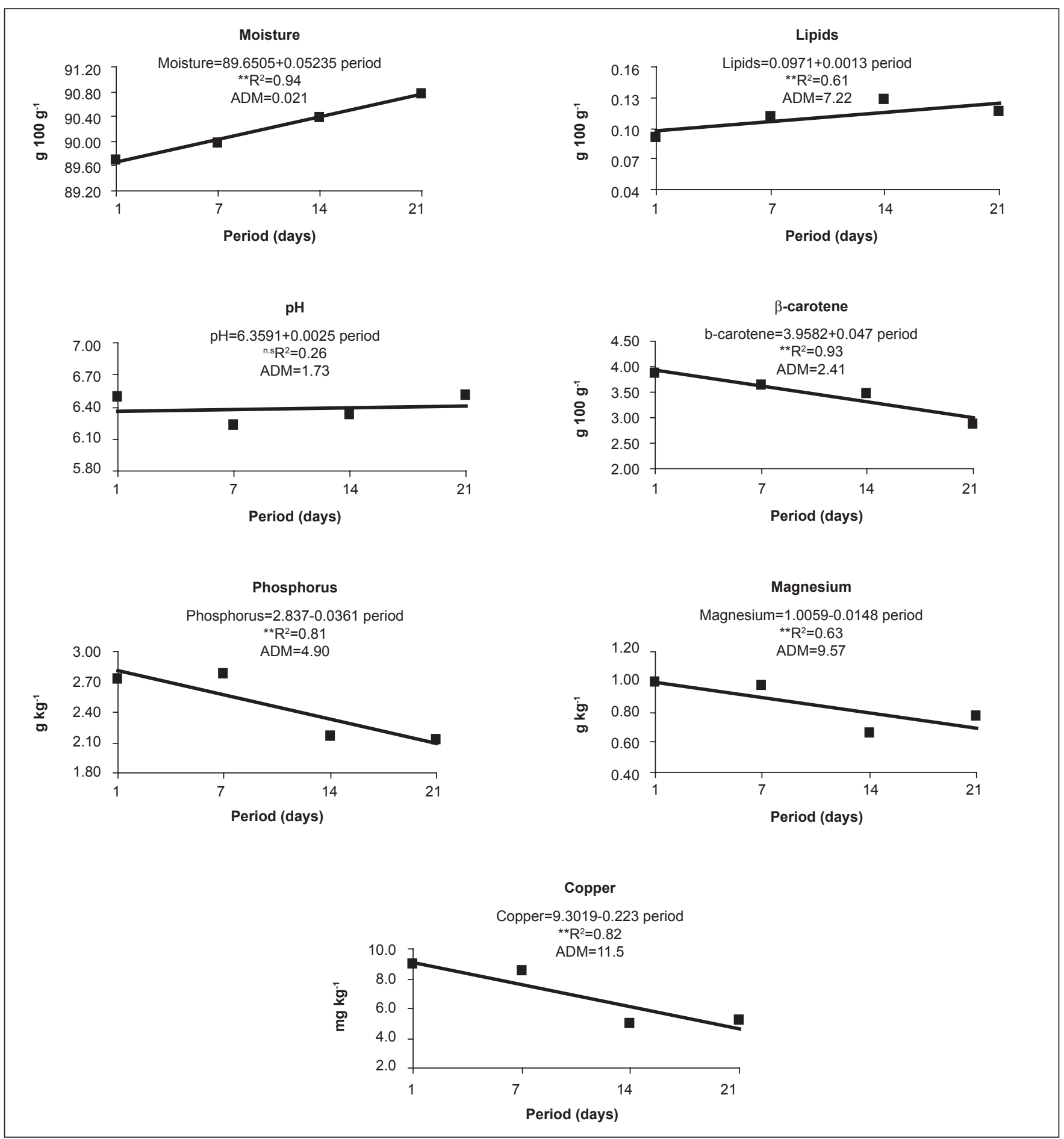

FIGURE 1 - Linear regression analysis for the components of carrot and corresponding statistics R-square and AMD (Average Mean Deviation) 
pepper contained total coliforms and anaerobic mesophiles (Table 4 ) and psychrotrophics during the storage period of all treatments (Table 5).

The refrigeration temperature below $7^{\circ} \mathrm{C}$ used in the storage of minimally processed fruits and vegetables extended the shelf life of these products, slowing down the microorganisms growth rate, but it is selective for psychro- trophic microorganisms. The presence of mesophile and psychrotrophic bacteria in lettuce, cabbage and chicory has been reported by some authors [29, 47]. Therefore, there is a concern about pathogens, such as the Listeria monocytogenes, which develop under refrigerated temperatures. BERRANG et al. [6] demonstrated that these microorganisms continued growing in asparagus, even if the sensory characteristics remained the same. SENESI et

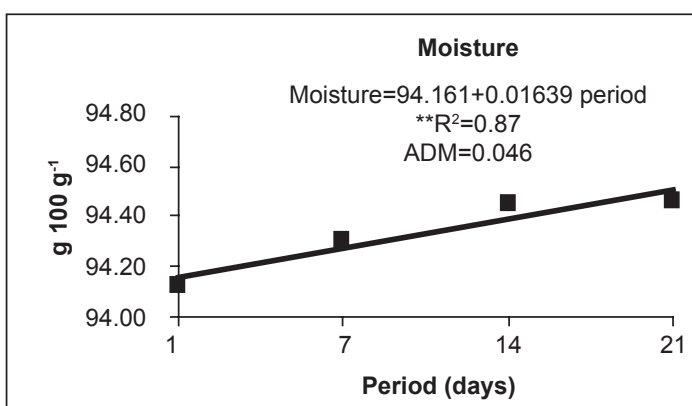

Ash

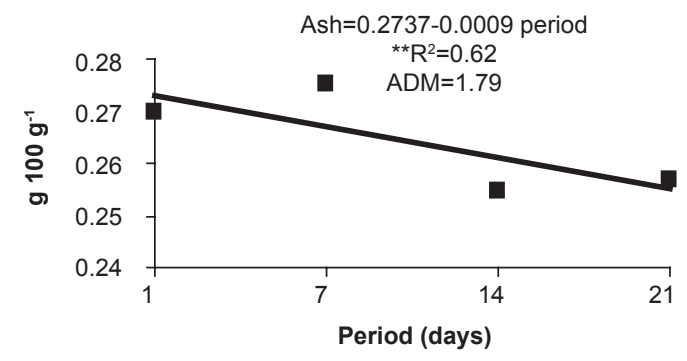

Vitamin C

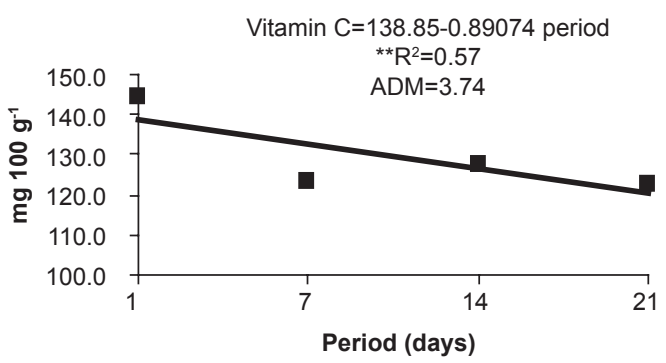

Phosphorus

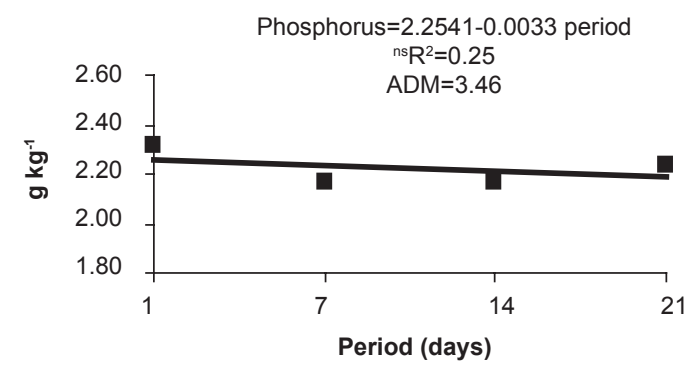

Lipids

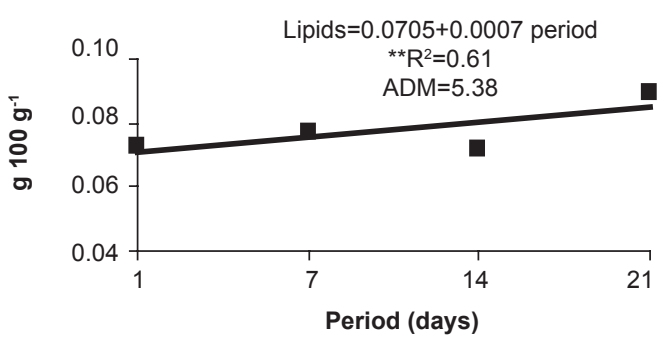

$\mathrm{pH}$

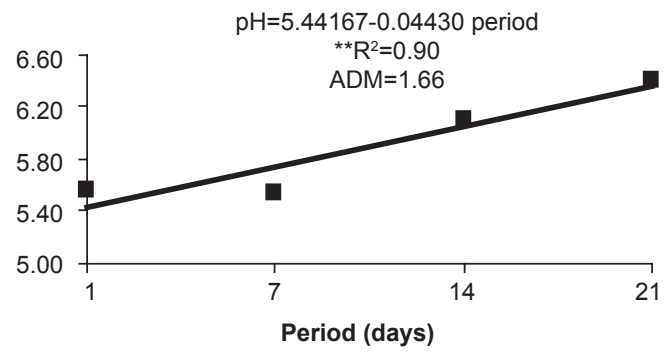

$\beta$-carotene
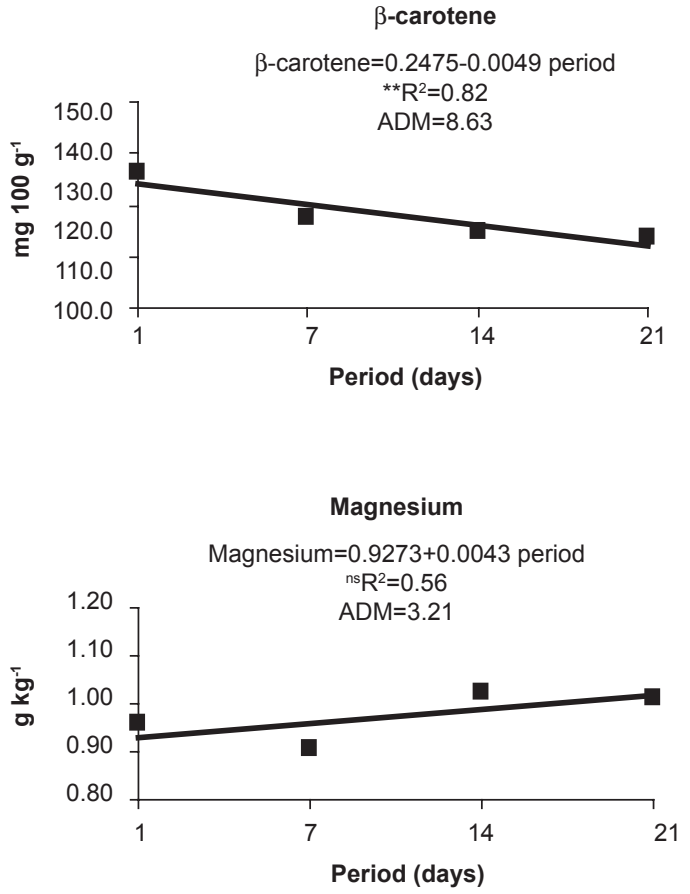

FIGURE 2 - Linear regression analysis for the components of green pepper and corresponding statistics R-square and AMD (Average Mean Deviation) 
al. [40] demonstrated that there was a fast proliferation of microorganisms, including lactic acid bacteria, in stored green peppers under modified atmosphere with high concentrations of $\mathrm{CO}_{2}$.

TABLE 4 - Total coliforms and anaerobic mesophiles in minimally processed green peppers, packed under air, vacuum and modified atmosphere (MA) stored under refrigeration at $1^{\circ} \mathrm{C} \pm 1^{\circ} \mathrm{C}$

\begin{tabular}{lcccc}
\hline \multirow{2}{*}{ Treatment } & \multicolumn{4}{c}{ Storage (days) } \\
& $\mathbf{1}$ & $\mathbf{7}$ & $\mathbf{1 4}$ & $\mathbf{2 1}$ \\
\cline { 2 - 4 } & \multicolumn{4}{c}{ Total Coliforms (MPN g ${ }^{-1}$ ) } \\
\hline Air & $<10 / \mathrm{g}$ & $<10 / \mathrm{g}$ & $<10 / \mathrm{g}$ & $4.0 \times 10$ \\
Vacuum & $<10 / \mathrm{g}$ & $4.6 \times 10^{2}$ & $<10 / \mathrm{g}$ & $<10 / \mathrm{g}$ \\
MA & $<10 / \mathrm{g}$ & $4.0 \times 10$ & $<10 / \mathrm{g}$ & $4.0 \times 10^{2}$ \\
\hline \multicolumn{5}{c}{ Anaerobic Mesophiles (CFU g-1) } \\
\hline Air & $2.3 \times 10^{3}$ & $4.2 \times 10^{3}$ & $3.0 \times 10^{4}$ & $7.4 \times 10^{5}$ \\
Vacuum & $1.6 \times 10^{3}$ & $4.2 \times 10^{3}$ & $3.4 \times 10^{4}$ & $6.6 \times 10^{5}$ \\
MA & $2.4 \times 10^{3}$ & $4.1 \times 10^{3}$ & $4.2 \times 10^{4}$ & $1.4 \times 10^{5}$ \\
\hline
\end{tabular}

TABLE 5 - Psychrotrophics in minimally processed carrots and green peppers, packed under air, vacuum and modified atmosphere (MA) stored under refrigeration at $1^{\circ} \mathrm{C} \pm 1^{\circ} \mathrm{C}$

\begin{tabular}{lcccc}
\hline \multirow{2}{*}{ Treatment } & \multicolumn{4}{c}{$\begin{array}{c}\text { Psychrotrophics }\left(\mathrm{CFU} \text { g }^{-1} \text { ) }\right. \\
\text { Storage (days) }\end{array}$} \\
\cline { 2 - 5 } & \multicolumn{4}{c}{$\mathbf{7}$ Carrots } \\
\cline { 2 - 4 } & $\mathbf{4}$ & $\mathbf{2 1}$ \\
\hline Air & $1.1 \times 10^{2}$ & $1.5 \times 10^{2}$ & $1.8 \times 10^{4}$ & $1.5 \times 10^{3}$ \\
Vacuum & $1.9 \times 10^{2}$ & $5.8 \times 10^{2}$ & $1.2 \times 10^{5}$ & $2.8 \times 10^{2}$ \\
MA & $3.5 \times 10^{2}$ & $6.0 \times 10^{2}$ & $9.0 \times 10^{3}$ & $7.0 \times 10^{2}$ \\
\hline \multicolumn{5}{c}{ Green peppers } \\
\hline Air & $8.3 \times 10^{2}$ & $4.9 \times 10^{3}$ & $1.0 \times 10^{6}$ & $6.9 \times 10^{5}$ \\
Vacuum & $3.5 \times 10^{3}$ & $6.4 \times 10^{3}$ & $4.0 \times 10^{5}$ & $5.9 \times 10^{5}$ \\
MA & $3.1 \times 10^{3}$ & $4.1 \times 10^{4}$ & $2.2 \times 10^{5}$ & $1.8 \times 10^{6}$ \\
\hline
\end{tabular}

In this research, the count of psychrotrophics in minimally processed carrot and green pepper in all treatments was $10^{2}$ to $10^{5}$ and $10^{3}$ to $10^{6} \mathrm{CFU} \mathrm{g} \mathrm{g}^{-1}$, respectively (Table 5). These counts were lower than those found by GARCÍA-GIMENO \& ZURERA-COSANO [14], who observed an increase of $10^{5}$ to $10^{7} \mathrm{CFU} \mathrm{g}^{-1}$ in the count of psychrotrophic microorganisms in mixed lettuce, carrot and purple cabbage salad packed in polypropylene film without gas injection for 9 days of storage under a temperature of $4^{\circ} \mathrm{C}$. The counts of psychrotrophic bacteria in minimally processed carrots, beetroot and mixed salad from different commercial brands were high with initial indices of $10^{6}$ to $10^{9} \mathrm{CFU} \mathrm{g}^{-1}$ [34].

The sanitary quality of minimally processed vegetables was studied by several authors, such as MANVELL \& ACKLAND [28] on mixed cabbage, carrot, onion and green pepper salad; GARG et al. [15] on cauliflower and spinach; KALLANDER et al. [23] on cabbage; BENNIK et al. [5] on wild chicory; NGUYEN-THE et al. [29] on chicory; ROBBS et al. [32] on celery; FRANCIS \& O'BEIRNE [11] on lettuce; JACKSENS et al. [20] on mixed lettuce, green pepper and cucumber salad and VALERO et al. [44] on garlic and in general, the products are safe when processed in hygiene conditions and stored under refrigeration temperatures.
Ready-to-eat salads and vegetables evaluated revealed that the vast majority (3.826 from 3.852 samples; 99.3\%) were of satisfactory or acceptable microbiological quality according to Public Health Laboratory Service microbiological guidelines, while $20(0.5 \%)$ samples were of unsatisfactory microbiological quality due to Escherichia coli and Listeria spp. levels in excess of $10^{1} \mathrm{CFU} \mathrm{g}$. However, six $(0.2 \%)$ samples were of unacceptable microbiological quality because of the presence of Salmonella, or because of a L. monocytogenes level of $660 \mathrm{CFU} \mathrm{g}^{-1}$, which indicates a health risk [37].

Listeria risk assessment, according to FAO/WHO, to $L$. monocytogenes in ready-to-eat foods at an international level ranges from absence in $25 \mathrm{~g}$ to 1.000 colonies forming units per gram or milliliter, or does not exceed specified levels at the point of consumption [35].

\section{4 - CONCLUSIONS}

Through the results of the physical-chemical, nutritional and microbiological analysis of the two products, we could observe similarities between the treatments carried out.

Carrot packed under air, vacuum and modified atmosphere and stored under at $1^{\circ} \mathrm{C}$, presented a low microbial contamination, showing the importance of the combined conservation methods for safer products with a longer shelf life.

Fecal and total coliforms, anaerobic mesophiles and Salmonella could not be observed in any of the treatments for the minimally processed carrot. Anaerobic mesophiles and total coliforms were present in minimally processed green pepper. Psychrotrophics were found in all the treatments of the minimally processed carrot and green pepper.

The content of vitamin $\mathrm{C}$ for the minimally processed carrot and green pepper did not present differences among treatments, however decreased during the storage period for the green pepper.

The content of $\beta$-carotene decreased slightly during the storage period for the minimally processed carrot and green pepper.

For the minimally processed carrot, the content of phosphorus, magnesium and copper decreased during the storage period. For the minimally processed green pepper, phosphorus and magnesium oscillated during the storage period.

\section{5 - LIBRARY REFERENCE}

[1] ABDUL-RAOUF, U.M.; BEUCHAT, L.R.; AMMAR, M.S. Survival and growth of Escherichia coli O157:H7 on salad vegetables, Applied and Environmental Microbiology, v. 59, p. 1999-2006, 1993.

[2] ASSOCIATION OF OFFICIAL ANALYTICAL CHEMISTS - AOAC, Official methods of analysis, $16^{\mathrm{a}}$ edição, Arlington: AOAC, 1995.

[3] ASSOCIATION OF OFFICIAL ANALYTICAL CHEMISTS - AOAC, Method validation programs, Disponível em: 
<http://www.aoac.org>, Acesso em 27 jan. 2002.

[4] BENEDETTI, B.C.; GOLINELLI, C.C.; SARANTÓPOULOS, C.I.G.L. Avaliação de pimentão minimamente processado em rodelas e tiras, armazenado nas temperaturas de 5 e $10^{\circ} \mathrm{C}$, In: CONGRESSO BRASILEIRO DE CIÊNCIA E TECNOLOGIA DE ALIMENTOS., Porto Alegre: SBCTA, n. 18, p.1241-1245, 2002.

[5] BENNIK, M.H.J.; PEPPELENBOS, H.W.; NGUYEN-THE, C. CARLIN, F.; SMID, E.J.; GORRIS, L.G.M. Microbiology of minimally processed, modified-atmosphere packaged chicory endive, Postharvest Biology and Technology, v. 9, p. 209-221, 1996.

[6] BERRANG, M.E.; BRACKETT, R.E.; BEUCHAT, L.R. Microbial, color and textural qualities of fresh asparagus, broccoli, and cauliflower stored under controlled atmosphere, Journal of Food Protection, v. 53, p. 391-395, 1990.

[7] BITTENCOURT, M.T.; VANETTI, M.C.D.; PUSCHMANN, R. Atividade microbiana em couve minimamente processada, In: ENCONTRO NACIONAL SOBRE PROCESSAMENTO MÍNIMO DE FRUTAS E HORTALIÇAS, Viçosa: UFV, n. 2, p. 42, 2000.

[8] CARLIN, F.; NGUYEN-THE, C.; CHAMBROY, Y.; REICH, M. Effects of controlled atmospheres on microbial spoilage, eletrolyte leakage and sugar content on fresh, read-to-use grated carrots, International Journal of Food Science and Technology, v. 25, p. 110-119, 1990.

[9] CHITARRA, M.I.F. Processamento mínimo de frutas e hortaliças, Tecnologia e Treinamento Agropecuário, v.2, p.7, 1999.

[10] FANTUZZI, E. Atividade microbiana em repolho (Brassica oleraceae cv. capitata) minimamente processado. Viçosa, 50p., Dissertação (Mestre em Tecnologia de Alimentos), Universidade Federal de Viçosa (UFV), 1999.

[11] FRANCIS, G.A.; O’BEIRNE, D. Effects of gas atmosphere, antimicrobial dip and temperature on the fate of $L$. innocua and L. monocytogenes on minimally processed lettuce, International Journal of Food Science and Technology, v. 32, p. 141-151, 1997.

[12] FRANCO, G. Tabela de composição química dos alimentos, 9. edição. São Paulo: ATHENEU, 1999.

[13] FURLANI, A.M.C.; FURLANI, P.R.; BATAGLIA, O.C.; HIROCE, R.; GALLO, J.R. Composição centesimal de diversas hortaliças, Bragantia, v. 37, p. 33-34, 1978.

[14] GARCÍA-GIMENO, R.M.; ZURERA-COSANO, G. Determination of ready-to-eat vegetable salad shelf-life, International Journal of Food Microbiology, v. 36, p. 31-38, 1997.

[15] GARG, N.; CHUREY, J.J.; SPLITTSTOESSER, D.F. Effect of processing conditions on the microflora of fresh-cut vegetables, Journal of Food Protection, v. 53, p. 701-703, 1990.

[16] GIL, M.I.; CONESA, M.A.; ARTÉS, F. Quality changes in fresh-cut tomato as affected by modified atmosphere packaging, Postharvest Biology and Technology, v. 25, p. 199-207, 2002.

[17] HUSSEIN, A.; ODUMERU, J.A.; AYANBADEJO, T.; FAULKNER, H.; MCNAB, W.B.; HAGER, H.; SZIJARTO, L. Effects of processing and packaging on vitamin $C$ and $\beta$-caroteno content of ready-to-use
(RTU) vegetables, Food Research International, v. 33, p. 131-136, 2000.

[18] INSTITUTO BRASILEIRO DE GEOGRAFIA E ESTATÍSTICA. Tabelas de composição dos alimentos, Rio de Janeiro: IBGE, 202p. (Estudo Nacional da Despesa Familiar, 3), 1977.

[19] IZUMI, H.; WATADA, A.E.; KO, N.P.; DOUGLAS, W. Controlled atmosphere storage of carrot slices, sticks and shreds, Postharvest Biology and Technology, v. 9, p. 165-172, 1996.

[20] JACKSENS, L.; DEVLIEGHERE, F.; DEBEVERE, J. Temperature dependence of shelf-life as affected by microbial proliferation and sensory quality of equilibrium modified atmosphere package fresh produce, Postharvest Biology and Technology, v. 26, p. 59-73, 2002.

[21] JAYAS, D.S.; JEYAMKONDAN, S. Modified atmosphere storage of grains, meats, fruits and vegetables, Biosystems Engineering, v. 82, p. 235-251, 2002.

[22] KAKIOMENOU, K.; TASSOU, C.; NYCHAS, G. Microbiological, physicochemical and organoleptic changes of shredded carrots stored under modified storage, International Journal of Food Science Technology, v. 31, p. 359-366, 1996.

[23] KALLANDER, K.D.; HITCHINS, A.D.; LANCETTE, G.A.; SCHMIEG, J.A.; GARCIA, G.R.; SOLOMON, H.M.; SOFOS, J.N. Fate of Listeria monocytogenes in shredded cabbage stored at 5 and $25^{\circ} \mathrm{C}$ under a modified atmosphere, Journal of Food Protection, v. 54, p. 302-304, 1991.

[24] LAMIKANRA, O.; WATSON, M.A. Biochemical changes associated with fresh-cut fruit processing and storage, Freshness and Shelf Life of Foods, v. 836, p. 52-68, 2003.

[25] LI, P.; BARTH, M.M. Impact of edible coatings on nutritional and physiological changes in lightly-processed carrots, Postharvest Biology and Technology, v. 14, p. 51-60, 1998.

[26] LUENGO, R. de F.A.; PARMAGNANI, R.M.; PARENTE, M.R.; LIMA, M.F.B.F. Tabela de composição nutricional de hortaliças, Brasília: EMBRAPA Hortaliças, 4p. (Documentos, 26), 2000.

[27] MALAVOLTA, E.; VITTI, G.C.; OLIVEIRA, S.A. de. Avaliação do estado nutricional das plantas: princípios e aplicações, $1^{\text {a }}$. edição, Piracicaba: ASSOCIAÇÃO BRASILEIRA PARA PESQUISA DA POTASSA E DO FOSFATO, 1989.

[28] MANVELL, P.M.; ACKLAND, M.R. Rapid detection of microbial growth in vegetable salads at chill and abuse temperatures, Food Microbiology, v. 3, p. 59-65, 1986.

[29] NGUYEN-THE, C.; HALNA-D.; U-FRÉTAY, B.; SILVA, A.A. The microbiology of mixed salad containing raw and cooked ingredients without dressing, International Journal of Food Science and Technology, v. 31, p. 481-487, 1996.

[30] PIGA, A.; DEL CARO, A.; PINNA, I.; AGABBIO, M. Changes in ascorbic acid, polyphenol content and antioxidant activity in minimally processed cactus pear fruits, Food Science and Technology, v. 36, p. 257-262, 2003.

[31] PREGNOlATtO, W.; PREGNOLATTO, N.P. Normas analíticas do Instituto Adolfo Lutz: métodos quími- 
cos e físicos para análise de alimentos, 3. edição, São Paulo: INSTITUTO ADOLFO LUTZ, 1985.

[32] ROBBS, P.G.; BARTZ, J.A.; MCFIE, G. HODGE, N.C. Causes of decay of fresh-cut celery, Journal of Food Science, v. 61, p. 444-455, 1996.

[33] RODRIGUEZ-AMAYA.; RAYMUNDO, L.C.; LEE, T.C.; SIMPSON, K.L.; CHICHSTER, C.O. Carotenoids pigments changes in ripenning Momordica charantia fruits, Annals of Botany, v. 40, p. 615-624, 1976.

[34] ROSA, O.O. Microbiota associada a produtos hortícolas minimamente processados comercializados em supermercados, Lavras, 120p., Tese (Doutora em Ciências dos Alimentos), Universidade Federal de Lavras (UFLA), 2002.

[35] ROCOURT, J.; BENEMBAREK, P.; TOYOFUKU, H.; SCHLUNDT, J. Quantitative risk assessment of Listeria monocytogenes in ready-to-eat foods: the FAO/WHO approach, Fems Immunology and Medical Microbiology, v. 35, p. 263-267, 2003.

[36] SARRUGE, J.R.; HAAG, H.P. Análises químicas em plantas, $1^{a}$. edição, Piracicaba: ESALQ, 1974.

[37] SAGOO, S.K.; LITTLE, C.L.; WARD, L.; GILLESPIE, I.A.; MITCHELL, R.T. Microbiological study of ready-to-eat salad vegetables from retail establishments uncovers a national outbreak of salmonellosis, Journal of Food Protection, v. 66, p. 403-409, 2003.

[38] SALTVEIT, M.E. Is it possible to find and optimal controlled atmosphere?, Postharvest Biology and Technology, v. 27, p. 3-13, 2003.

[39] SCOTT, V.N. Interaction of factors to control microbial spoilage of refrigerated foods, Journal of Food Protection, v. 52, p. 431-435, 1989.

[40] SENESI, E.; PRINZIVALLI, C.; SALA, M.; GENNARI, M. Physicochemical and microbiological changes in fresh-cut green bell peppers as affected by packaging and storage, Italian Journal of Food Science, v. 12, p. 55-64, 2000.
[41] SILVA, N. da.; JUNQUEIRA, V.C.A.; SILVEIRA, N.F.A. Manual de métodos de análise microbiológica de alimentos, $1^{\mathrm{a}}$. edição, São Paulo: LIVRARIA VARELA, 1997.

[42] TELES, C.S.; RAMOS, A.M.; PUSCHMANN, R.; CAMPOS, R.S. Embalagens plásticas para conservação de couve minimamente processada sob atmosfera modificada ativa, In: ENCONTRO NACIONAL SOBRE PROCESSAMENTO MÍNIMO DE FRUTAS E HORTALIÇAS, Viçosa: UFV, n. 2, p.39, 2000.

[43] UNIVERSIDADE DE SÃO PAULO. Tabela brasileira de composição de alimentos, Disponível em: < http://fcf.usp. br/tabela/tbcamenu.php>, Acesso em: 15 nov., 2001.

[44] VALERO, M.; HERNÁNDEZ-HERRERO, L.A.; FERNÁNDEZ, P.S.; SALMERÓN, M.C. Characterization of Bacillus cereus isolates from fresh vegetables and refrigerated minimally processed foods by biochemical and physiological tests, Food Microbiology, v. 19, p. 491-499, 2002.

[45] VANDERZANT, C.; SPLITTSTOESSER, D.F. Compendium of methods for the microbiological examination of foods, $1^{\text {a }}$. edição, Washington: APHA, 1992.

[46] ZAGORY, D.; KADER, A.A. Modified atmosphere packaging of fresh produce, Food Technology, v. 42, p. 70-77, 1988.

[47] ZANGH, S.; FARBER, J.M. The effects of various disinfectants against Listeria monocytogenes on fresh-cut vegetables, Food Microbiology, v. 13, p. 311-321, 1996.

[48] ZONTA, E.P.; MACHADO, A.M.; SILVEIRA JR., P. SANEST: sistema de análise estatística para microcomputadores, $1^{\mathrm{a}}$. edição, Pelotas: UNIVERSITÁRIA, 1986.

\section{6 - ACKNOWLEDGEMENTS}

To FAPESP (Fundação de Amparo à Pesquisa do Estado de São Paulo) for financial support. 